Check for updates

Cite this: RSC Adv., 2017, 7, 37797

\title{
Analysis and modeling of the growth of intermetallic compounds in aluminum-steel joints
}

\author{
Gang Zhang, ${ }^{a}$ ManJiao Chen, ${ }^{a}$ Yu Shi, ${ }^{\text {a }}$ Jiankang Huang ${ }^{a}$ and Fuqian Yang (D) *b
}

In this work, we experimentally and numerically studied the microstructures and growth of intermetallic compounds (IMCS) formed in Al-Fe (aluminum-steel) joints welded by a pulsed double electrode gas metal arc welding (DE-GMAW)-brazing method. The IMCs consist of $\mathrm{Fe}_{2} \mathrm{Al}_{5}$ and $\mathrm{FeAl}_{3}$, with $\mathrm{Fe}_{2} \mathrm{Al}_{5}$ being the main compound in the joints. The thickness of an IMC layer increases with an increase of the welding current (heat input) into the base metal. EBSD measurement suggests that the preferred crystal orientation of the $\mathrm{Fe}_{2} \mathrm{Al}_{5} \mathrm{IMC}$ likely provides the necessary path for $\mathrm{Al}$ atoms to migrate through the IMC layer for further growth of the $\mathrm{Fe}_{2} \mathrm{Al}_{5} \mathrm{IMC}$ layer toward the steel substrate. The Monte Carlo method was used to simulate growth of the IMCs in the joints. Numerical results are in good accord with the experimental results, suggesting that $\mathrm{Fe}_{2} \mathrm{Al}_{5} \mathrm{IMC}$ is first formed in the initial brazing interface between liquid $\mathrm{Al}$ and steel substrate, and then the interface between the liquid $\mathrm{Al}$ and steel substrate evolves into two new interfaces: one is an interface between the $\mathrm{Fe}_{2} \mathrm{Al}_{5} I M C$ layer and the steel substrate, and the other is an interface between the $\mathrm{Fe}_{2} \mathrm{Al}_{5} I \mathrm{MC}$ layer and liquid Al. During growth of the $\mathrm{Fe}_{2} \mathrm{Al}_{5} I M C, \mathrm{FeAl}_{3}$ $I M C$ forms in the interface between the $\mathrm{Fe}_{2} \mathrm{Al}_{5} I \mathrm{MC}$ layer and the $\mathrm{Al}$ and then grows into the Al. The thickness of the $\mathrm{Fe}_{2} \mathrm{Al}_{5}$ layer increases nonlinearly with an increase in the growth time.

Received 7th June 2017

Accepted 20th July 2017

DOI: $10.1039 / \mathrm{c} 7 \mathrm{ra0} 6354 \mathrm{~g}$

rsc.li/rsc-advances
$(\mathrm{CMT}),{ }^{8}$ gas metal arc welding (GMAW), ${ }^{9}$ laser welding, and laser-arc hybrid welding. ${ }^{10,11}$ Solid-state bonding methods can efficiently suppress formation of Al-Fe IMCs in a joint interface due to low heat input to the base metal. However, these methods cannot completely limit the formation of Al-Fe IMCs and can only produce Al-Fe joints with limited strength.

It has been reported that the thickness of an Al-Fe IMC layer formed in a brazed interface can be limited to less than $10 \mu \mathrm{m}$, which is the critical thickness of the Al-Fe IMC layer for an AlFe joint with good mechanical strength. ${ }^{12}$ Analysis of the microstructures of Al-Fe joints suggest that the microstructures and distribution of Al-Fe IMCs near the fusion-brazed Al-Fe joint interfaces are dependent on heat input into the base metal and play important roles in determining mechanical and/or corrosion behavior of the joints. ${ }^{13,14}$ However, there are few studies focusing on correlation between the welding current (heat input) and thickness of the Al-Fe IMC layer in joints formed by the fusion-brazing method. Especially, mechanisms for the formation and growth of Al-Fe IMCs remain elusive.

Das et al. ${ }^{15}$ proposed a theoretical-experimental method to estimate the thickness of the Al-Fe IMC layer in a lap configuration. Song et al. ${ }^{16}$ studied the microstructures of butt joints made by the TIG welding-brazing method and composition of the Al-Fe IMC layer. Madhavan et al. ${ }^{17}$ analyzed the effect of heat input on the microstructures, and the mechanical and corrosion behavior of Al-Fe joints. Zhang et al.,$^{18}$ Shao et al. ${ }^{19}$ and Chen et al. $^{20}$ numerically investigated formation of Al-Fe IMCs for given welding conditions from the framework of heat conduction and 
kinetics of solidification. However, their results did not reveal the intrinsic behavior involving formation and growth of the $\mathrm{Al}-\mathrm{Fe}$ IMCs due to limited information from experimental results.

Considering the applications of $\mathrm{Al}-\mathrm{Fe}$ dissimilar joints in automotive and rail transit industries, a DE-GMAW-brazing method was used in this work to join $\mathrm{Al}$ alloy to galvanized steel. The microstructures of the Al-Fe joints were analyzed by EBSD (electron backscatter diffraction). The Monte Carlo (MC) method incorporated with thermal and diffusion analyses was used to simulate growth of the Al-Fe IMCs.

\section{Experimental details and modeling analysis}

\subsection{Materials}

The materials used in this work were Al alloy wire (ER5356) of $1.2 \mathrm{~mm}$ in diameter and galvanized steel (Q235 mild steel) sheet coated with a $\mathrm{Zn}$ layer of $100 \mathrm{~g} \mathrm{~m}^{-2}$. Table 1 lists the chemical compositions of Q235 mild steel and ER5356 wire. The dimensions of the steel plate were $300 \times 100 \times 2 \mathrm{~mm}^{3}$. Prior to welding, the surface of the steel plate was cleaned with acetone to remove grease and surface residues.

\subsection{Welding process}

Fig. 1 shows the welding process by the pulsed DE-GMAWbrazing method. Detailed information can be found in the work of Shi et al. ${ }^{21}$ Briefly, a GTAW torch is inserted between the GMAW torch and the workpiece to decouple the welding current ( $\left.I_{\text {bypass }}\right)$ from total current $\left(I_{\text {total }}\right)$, which reduces the welding current $\left(I_{\text {main }}\right)$ into the base metal, i.e., $I_{\text {main }}=I_{\text {total }}-I_{\text {bypass }}$. This allows control of the welding current (heat input) into the base metal through control of $I_{\text {bypass }}$ and stable transfer of a molten droplet even with low heat input into the workpiece. However, introduction of the bypass torch itself cannot completely meet the requirement to join $\mathrm{Al}$ alloy to steel, which requires further reduction of the heat input. Instead, pulsed currents are used for both main and bypass loops. Synchronously controlling current waveforms of the main and bypass currents makes it possible to precisely control heat input into the base metal, and allows free transfer of molten droplets from the wire tip to the weld pool with a welding current much less than the current needed to realize the transfer of spray metal in a conventional GMAW process. Table 2 lists the welding parameters used for the formation of four bead-on-plate weld beads.

\subsection{Characterization of microstructures}

Specimens for analysis of microstructures were cut from beads along the direction perpendicular to the welding direction of the

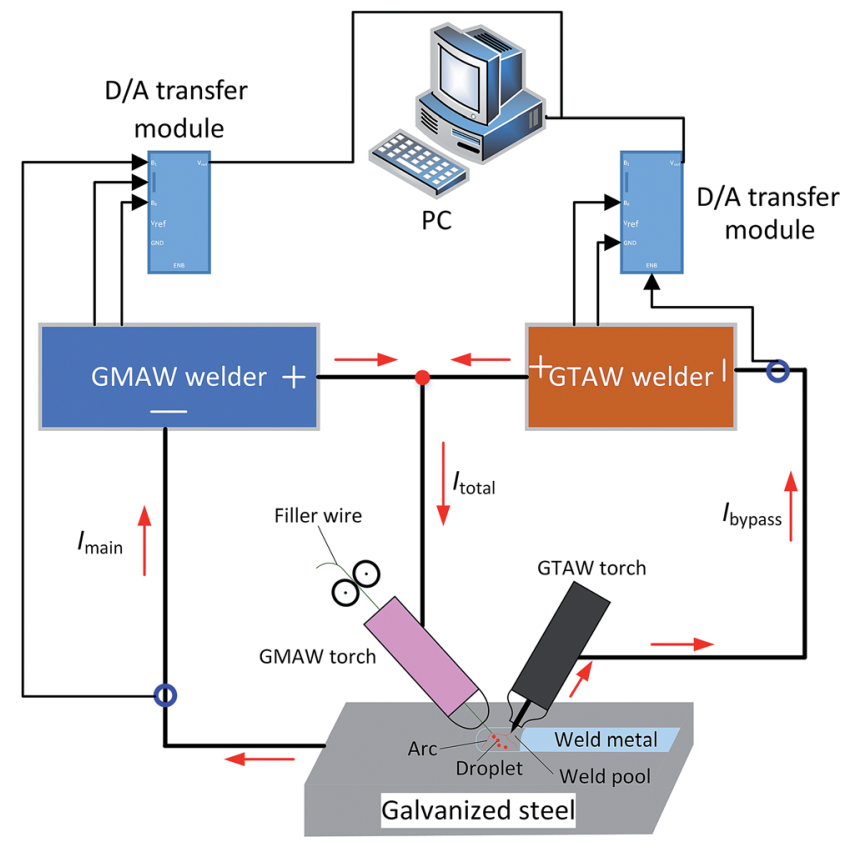

Fig. 1 Schematic diagram of the pulsed DE-GMAW-brazing process.

joints. The cross-section of the specimens was mechanically ground with wet-abrasive papers and polished to achieve a mirror-like surface. Surface etching was performed in a 0.5 vol\% HF solution. SEM (scanning electron microscopy) was used to characterize the microstructures of the Al-Fe joints. XRD (X-ray diffraction) and EDS (energy dispersive spectrometry) were used to analyze composition of the Al-Fe IMCs, and EBSD was used to measure crystal orientation and texture of the Al-Fe IMCs.

\subsection{Numerical modeling}

To understand formation and growth of the Al-Fe IMCs during welding, the MC method with dual layer lattices was used in numerical simulation, and the Cellular Automata (CA) theory incorporated with thermal calculation was used to analyze the fluctuation of energy over a micro-area in a liquid phase. Fig. 2 schematically shows the lattices used in the MC analysis. Migration of the interfaces was tracked from changes in the lattices.

2.4.1 Thermal analysis. It is known that the formation and growth of Al-Fe IMCs is dependent on local temperature and change of the concentrations of solute atoms. ${ }^{22,23}$ To simplify the analysis of heat conduction, the heat conduction involved in the joining process was approximated as a one-dimensional problem, as shown in Fig. 3, with the focus on temperature variation near the interface between the Al alloy and steel,

Table 1 Chemical compositions of ER5356 wire and Q235 mild steel (wt\%)

\begin{tabular}{lllllllllllll}
\hline Material & $\mathrm{Mg}$ & $\mathrm{Cr}$ & $\mathrm{C}$ & $\mathrm{Si}$ & $\mathrm{Cu}$ & $\mathrm{Fe}$ & $\mathrm{Zn}$ & $\mathrm{S}$ & $\mathrm{Mn}$ & $\mathrm{P}$ & $\mathrm{Ti}$ & $\mathrm{Al}$ \\
\hline ER5356 & 5.0 & 0.1 & - & 0.3 & 0.05 & 0.40 & 0.05 & - & 0.15 & - & 0.01 & Balance \\
Q235 & - & - & 0.12 & 0.30 & - & Balance & - & 0.045 & 0.30 & 0.045 & - & -
\end{tabular}


Table 2 Welding parameters

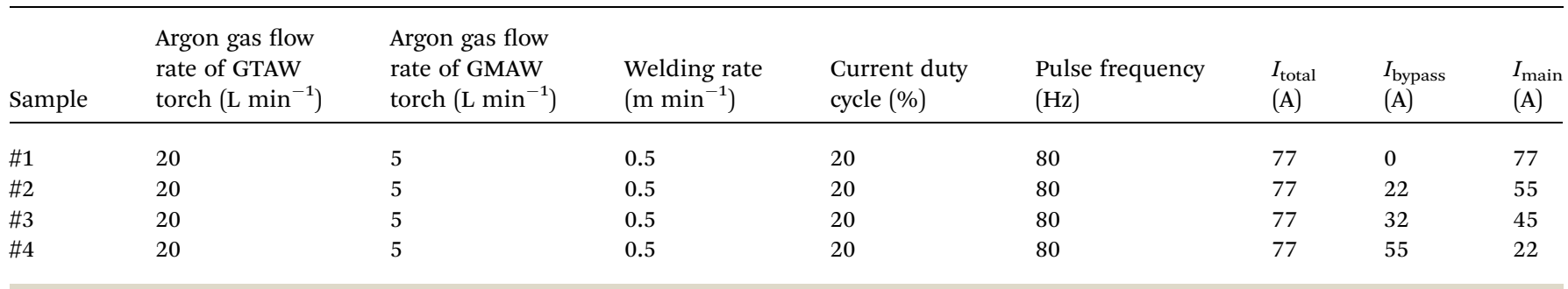

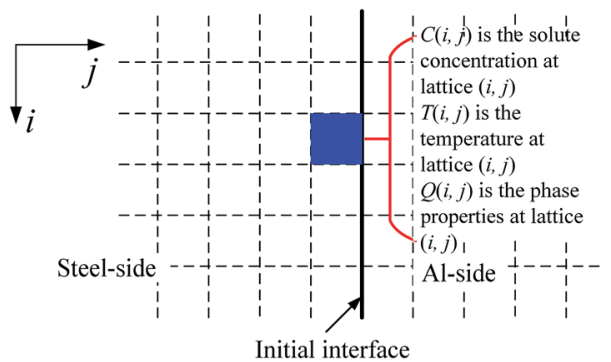

Fig. 2 Schematic diagram of two-dimensional lattices used in the MC simulation.

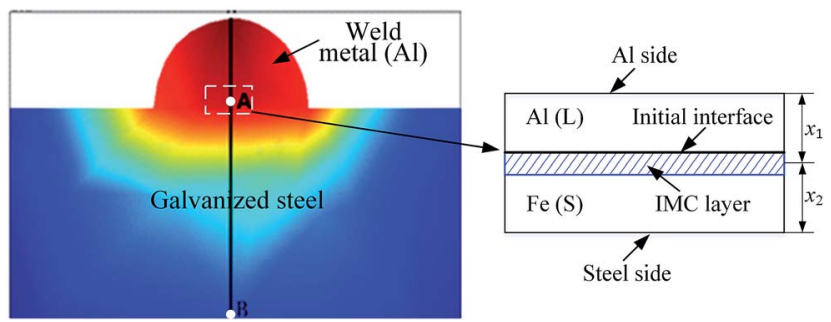

Fig. 3 Geometrical domain for analysis of heat conduction involved in the joining of an ER5356 filler wire to a steel plate.

which was used in the analysis of the growth of the Al-Fe IMCs. The edge effect of domain on the heat conduction was assumed to be negligible.

Following the method given by Shi et al.,,$^{22,23}$ the following assumptions were used in the calculation of the temperature distribution during joining.

(1) The heat source linearly distributes in the $\mathrm{Al}$ alloy, and there is no spatial variation of temperature along the edge of the $\mathrm{Al}$ alloy at any time of $t$.

(2) Temporal variation of the edge temperature of the Al alloy can be described by a Gaussian function.

(3) Constant flux condition can be used to describe heat conduction on the edge of the steel, as suggested by Shi $e t$ al. ${ }^{23}$

(4) The heat conduction in the region shown in Fig. 3 can be described as a one-dimensional problem.

The following relationships were used in analyzing the heat conduction near the Al-Fe interface.

$$
\begin{gathered}
T_{\mathrm{j}}=T_{\mathrm{r}}-q x_{2} / \lambda_{\mathrm{Al}} \text { with } q=\left(T_{\mathrm{r}}-T_{\mathrm{s}}\right) /\left(x_{1} \lambda_{\mathrm{Fe}}{ }^{-1}+x_{2} \lambda_{\mathrm{Al}}{ }^{-1}\right) \\
T_{-} \operatorname{cell}_{(\mathrm{Al})}=T_{\mathrm{r}}-\left(T_{\mathrm{r}}-T_{\mathrm{j}}\right)\left(n_{1} \lambda_{\mathrm{Al}}{ }^{-1}\right)\left(\lambda_{\mathrm{Al}} x_{1}{ }^{-1}\right)
\end{gathered}
$$

$$
T_{-} \operatorname{cell}_{(\mathrm{Fe})}=T_{\mathrm{j}}-\left(T_{\mathrm{j}}-T_{\mathrm{s}}\right)\left(n_{2} \lambda_{\mathrm{Fe}}{ }^{-1}\right)\left(\lambda_{\mathrm{Fe}} x_{2}{ }^{-1}\right)
$$

where $T_{\mathrm{j}}$ is the temperature of the Al-Fe interface, $T_{\mathrm{r}}$ is the edge temperature of the $\mathrm{Al}$ alloy, $T_{\mathrm{S}}$ is the edge temperature of the steel, $q$ is the heat flux, $x_{1}$ is the distance away from the edge of the $\mathrm{Al}$ alloy to the $\mathrm{Al}-\mathrm{Fe}$ interface, $x_{2}$ is the distance between the edge of the steel and the Al-Fe interface, $\lambda_{\mathrm{Al}}$ is the heat conductivity of the $\mathrm{Al}$ alloy, $\lambda_{\mathrm{Fe}}$ is the heat conductivity of the steel, $T_{-}$cell $_{(\mathrm{Al})}$ is the temperature of the cell in the $\mathrm{Al}$ alloy, $T_{-} \operatorname{cell}_{(\mathrm{Fe})}$ is the temperature of the cell in the steel, $n_{1}$ is the distance of the cell in the $\mathrm{Al}$ alloy to the heat source, and $n_{2}$ is the distance of the cell in the steel to the edge of the steel. Both $T_{\mathrm{r}}$ and $T_{\mathrm{S}}$ vary during joining, and the values are determined from the method given by Shi et al. ${ }^{22}$

2.4.2 Mass transport. Migration of solute atoms ( $\mathrm{Al}$ and $\mathrm{Fe}$ ) was analyzed on the assumptions that the migration is onedimensional, and there is no interaction between the diffusion of $\mathrm{Al}$ and Fe. Also, the effect of growth of the Al-Fe IMCs on the diffusion of $\mathrm{Al}$ and $\mathrm{Fe}$ was assumed to be negligible. The equation describing the diffusion of $\mathrm{Al}$ and $\mathrm{Fe}$ is written as

$$
\frac{\partial C}{\partial t}=\frac{\partial}{\partial x}\left(D \frac{\partial C}{\partial x}\right)
$$

with

$$
D=D_{0} \exp \left(\frac{-E_{\mathrm{A}}}{R T}\right)
$$

here, $C$ is the concentration of solute atoms, $D$ is the diffusion coefficient, $D_{0}$ is the pre-constant, $x$ is the $x$-coordinate, $E_{\mathrm{A}}$ is the activation energy, and $R$ is the gas constant of $8.314 \mathrm{~J} \mathrm{~mol}^{-1} \mathrm{~K}^{-1}$.

There are two diffusion processes for the diffusion of $\mathrm{Al}$ and Fe. One involves the diffusion of $\mathrm{Al}$ atoms in the steel and the diffusion of $\mathrm{Fe}$ in the $\mathrm{Al}$ alloy, and the other involves the diffusion of $\mathrm{Al}$ and $\mathrm{Fe}$ atoms through the Al-Fe IMCs.

2.4.3 Growth model. In the MC simulation, the formation and growth of the Al-Fe IMCs were determined by the lattice properties, i.e., the lattices possess the properties of materials (crystals). The growth of IMCs is incorporated in the first MC lattices, and the controlling factors are assigned in the second MC lattices. For detailed information, see the work by Shi et $a l .{ }^{24}$

\section{Results and discussion}

\subsection{Microstructures}

Fig. 4 shows optical images of a weld bead via the pulsed DEGMAW-brazing method and the corresponding cross-section 

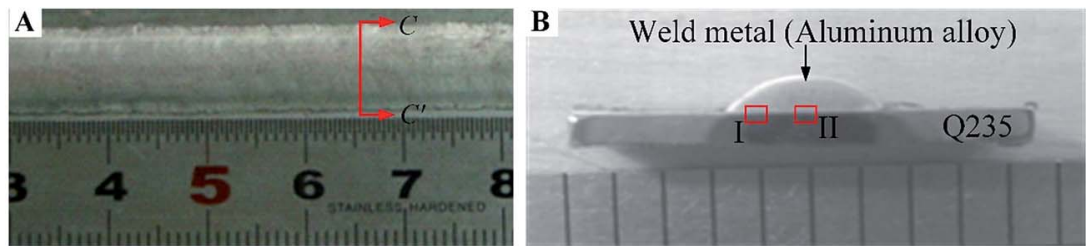

Fig. 4 Optical images of a weld bead and the corresponding cross-section of the weld bead.

of the weld bead. It is evident that the Al alloy was smoothly welded to the steel plate. The surface of the joint can be approximated as a segment of a circle, which supports the schematic diagram shown in Fig. 3.

Fig. 5 shows SEM images of microstructures near the Al-Fe interface for $I_{\text {total }}=77 \mathrm{~A}$. It is evident that a layer of interphase is formed between the $\mathrm{Al}$ alloy and the steel, which displays two different morphologies. The interface between the interphase and the steel is a plate-like shape, and the other interface between the interphase and the Al alloy is a zig-zag shape with discrete needle-like structures distributed in the Al alloy. There are no needle-like structures in the steel. Both the thickness of the interphase layer and the number of the discrete needle-like structures decrease with a decrease of the welding current (heat input) into the base metal.

XRD analysis was performed on the surfaces of a peeled weld seam specimen. Fig. 6 shows the XRD pattern. It is interesting to note that $\mathrm{Fe}_{2} \mathrm{Al}_{5}$ is presented on both surfaces, suggesting that the interphase layer consists of $\mathrm{Fe}_{2} \mathrm{Al}_{5}$ IMC. Joining of the $\mathrm{Al}$ alloy to the steel plate leads to the formation of a layer of $\mathrm{Fe}_{2} \mathrm{Al}_{5}$ IMC, which is sandwiched between the $\mathrm{Al}$ alloy and steel plate.

EDS analysis was used to estimate composition of the IMCs. Fig. 7 shows the locations at which EDS analysis was performed, and Table 3 lists the compositions of these two locations. According to the data in Table 3, one can conclude that the needle-like IMCs are $\mathrm{FeAl}_{3}$, and the interphase is $\mathrm{Fe}_{2} \mathrm{Al}_{5} \mathrm{IMC}$ in accord with the XRD analysis. Most IMCs are presented in the $\mathrm{Fe}_{2} \mathrm{Al}_{5}$ phase, which likely plays an important role in determining the mechanical behavior of the Al-Fe joints. ${ }^{25,26}$

\subsection{EBSD analysis of $\mathrm{Fe}_{2} \mathrm{Al}_{5}$ IMC}

EBSD analysis was performed on the areas of I and II shown in Fig. 4. Fig. 8 shows the EBSD mapping of area II in Fig. 4 for four different weld beads prepared with the welding parameters listed in Table 2. The $\mathrm{Fe}_{2} \mathrm{Al}_{5}$ IMC layer, which is sandwiched between the $\mathrm{Al}$ alloy and the steel, is a lath-like shape. The

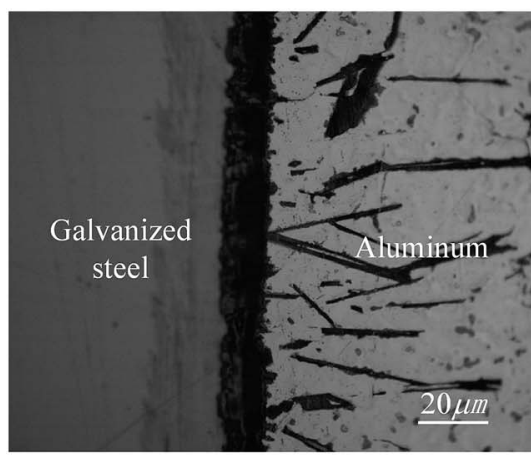

(a)

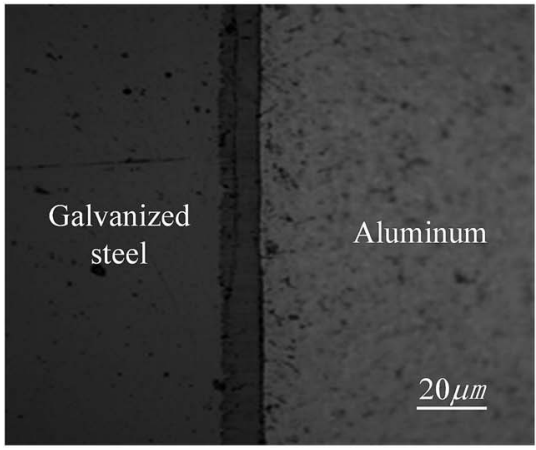

(c)

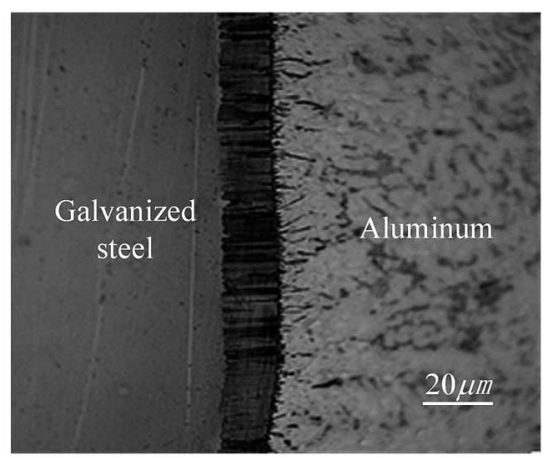

(b)

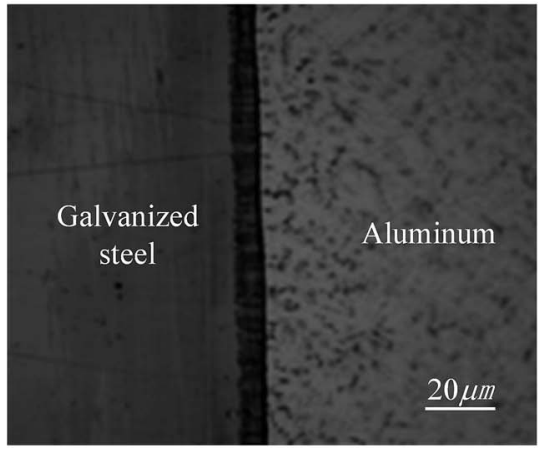

(d)

Fig. $5 \mathrm{SEM}$ images showing the microstructures near the Al-Fe interface; (a) $I_{\text {bypass }}=0 \mathrm{~A}$ and $I_{\text {main }}=77 \mathrm{~A}$, (b) $I_{\text {bypass }}=22 \mathrm{~A}$ and $I_{\text {main }}=55 \mathrm{~A}$, (c) $I_{\text {bypass }}=32 \mathrm{~A}$ and $I_{\text {main }}=45 \mathrm{~A}$, and $(\mathrm{d}) I_{\text {bypass }}=55 \mathrm{~A}$ and $I_{\text {main }}=22 \mathrm{~A}$. 


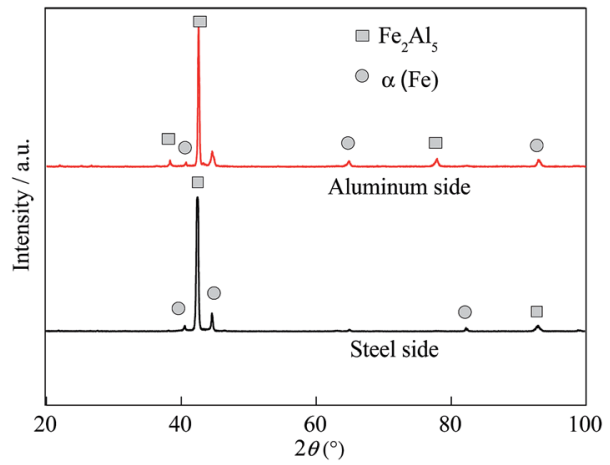

Fig. 6 XRD pattern of the surfaces of a peeled weld seam specimen.

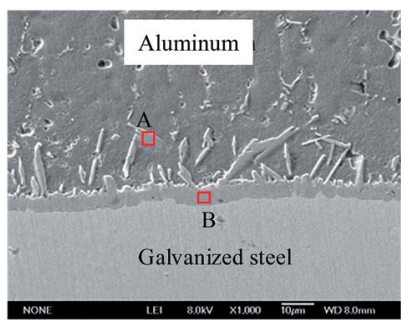

Fig. 7 SEM image showing the locations for the EDS analysis.

Table 3 Chemical compositions of the spots of A and B in Fig. 7

\begin{tabular}{llllll}
\hline & wt\% & & & at\% & \\
\cline { 2 - 3 } Location & $\mathrm{Fe}$ & $\mathrm{Al}$ & & $\mathrm{Fe}$ & $\mathrm{Al}$ \\
\hline $\mathrm{A}$ & 39.97 & 56.00 & & 23.94 & 69.42 \\
$\mathrm{~B}$ & 23.72 & 68.97 & & 32.72 & 76.54
\end{tabular}

growth direction of the $\mathrm{Fe}_{2} \mathrm{Al}_{5}$ IMC layer is perpendicular to the interface between the $\mathrm{Al}$ alloy and the steel before joining. Preferred crystal orientation for growth is the normal direction of the (001) plane, i.e., the growth direction of the $\mathrm{Fe}_{2} \mathrm{Al}_{5} \mathrm{IMC}$ formed in the pulsed DE-GMAW joining is the same as the direction of $c$-axis of the $\mathrm{Fe}_{2} \mathrm{Al}_{5}$ IMC. ${ }^{27}$ Both the size of the $\mathrm{Fe}_{2} \mathrm{Al}_{5}$ IMC and thickness of the IMC layer increased with an increase of the welding current (heat input) into the base metal, and the $\mathrm{Fe}_{2} \mathrm{Al}_{5}$ IMC is orderly distributed between the $\mathrm{Al}$ alloy and the steel (Fig. 8a). Such behavior is likely due to the large welding current (heat input) that causes the steel to melt and accelerates diffusion of $\mathrm{Fe}$ into the molten $\mathrm{Al}$ to form a large amount of $\mathrm{Fe}_{2} \mathrm{Al}_{5}$ IMC. From Fig. 8, one can note that the morphology of the $\mathrm{Fe}_{2} \mathrm{Al}_{5}$ IMC becomes relatively more random and disordered, and the orientation of the $\mathrm{Fe}_{2} \mathrm{Al}_{5}$ IMC deviates from the normal direction of the (001) plane (Fig. 8d).

Fig. 9 shows EBSD mapping of area I in Fig. 4 for four different weld beads prepared with the welding parameters listed in Table 2. The $\mathrm{Fe}_{2} \mathrm{Al}_{5}$ IMCs are presented in smallish lath-like shapes, and distributed more randomly than in area II for the same welding conditions. This trend is likely due to a lower temperature near the edge of the weld bead. Increasing

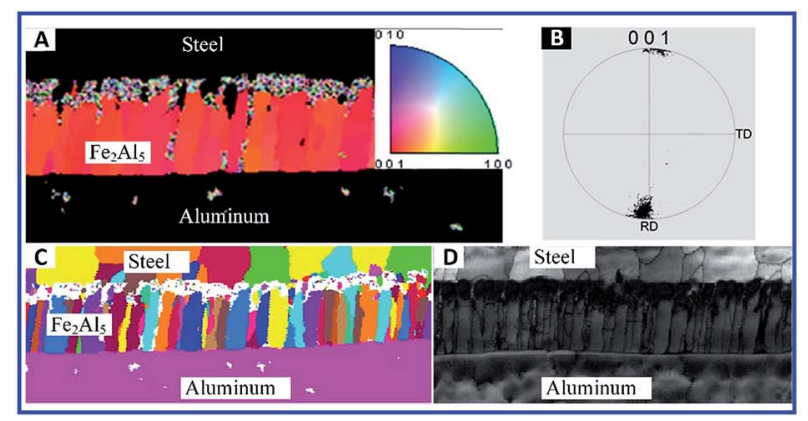

(a)

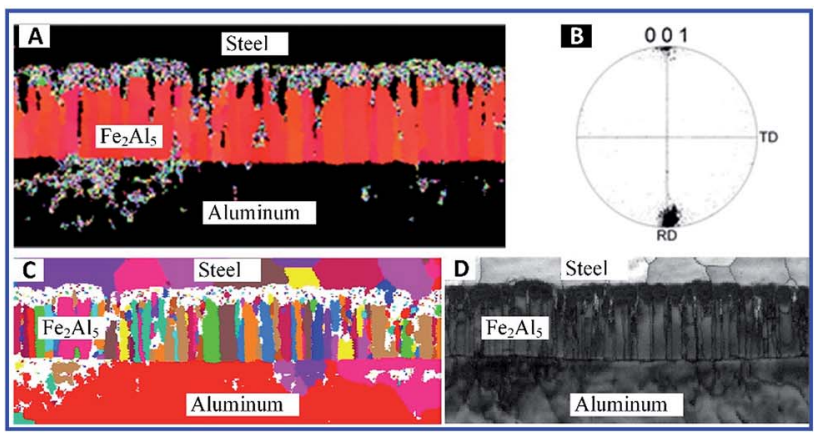

(b)

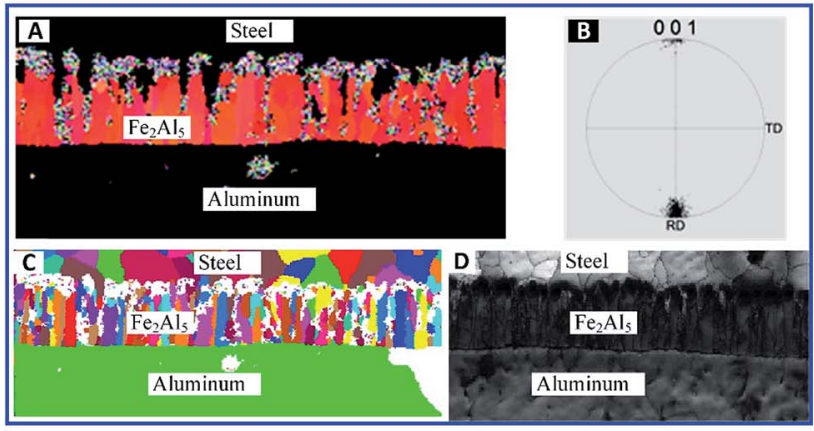

(c)

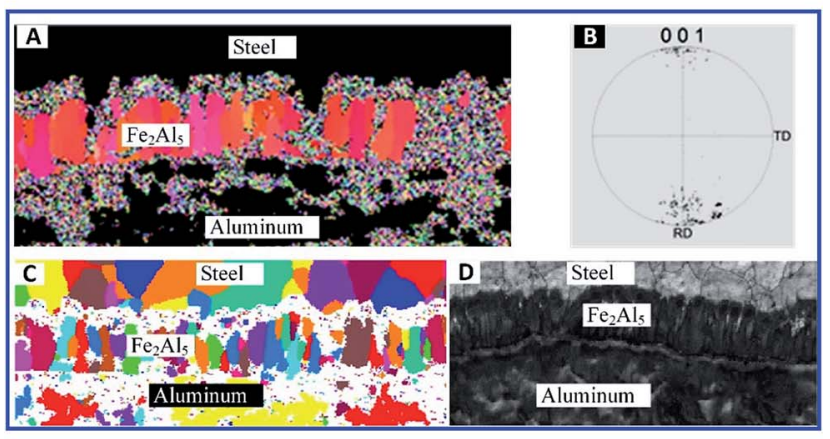

(d)

Fig. 8 EBSD mapping of area II in Fig. 4 for four different weld beads prepared with the welding parameters listed in Table $2\left(I_{\text {total }}=77 \mathrm{~A}\right.$, (A) image of crystal orientation, (B) pole figure, (C and D) EBSD color, black-white images of the joint); (a) $I_{\text {bypass }}=0 \mathrm{~A}$ and $I_{\text {main }}=77 \mathrm{~A}$, (b) $I_{\text {bypass }}=22 \mathrm{~A}$ and $I_{\text {main }}=55 \mathrm{~A}$, (c) $I_{\text {bypass }}=32 \mathrm{~A}$ and $I_{\text {main }}=45 \mathrm{~A}$, and (d) $I_{\text {bypass }}=55 \mathrm{~A}$ and $I_{\text {main }}=22 \mathrm{~A}$. 


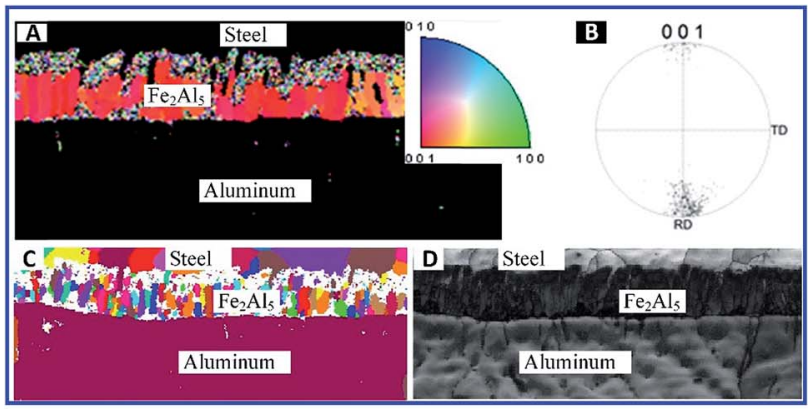

(a)

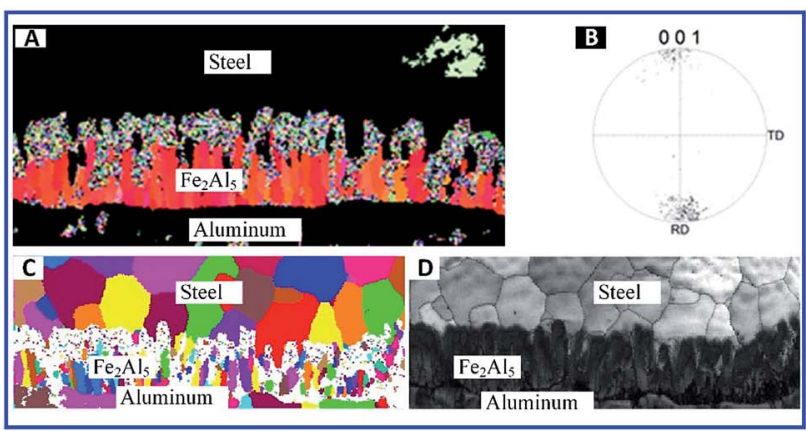

(b)

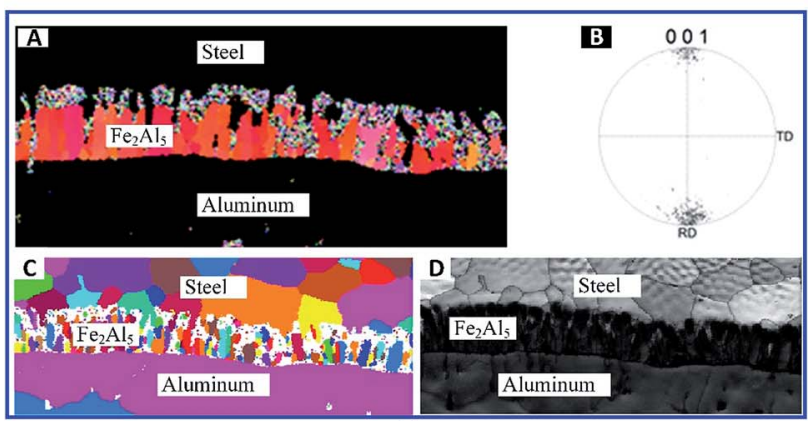

(c)

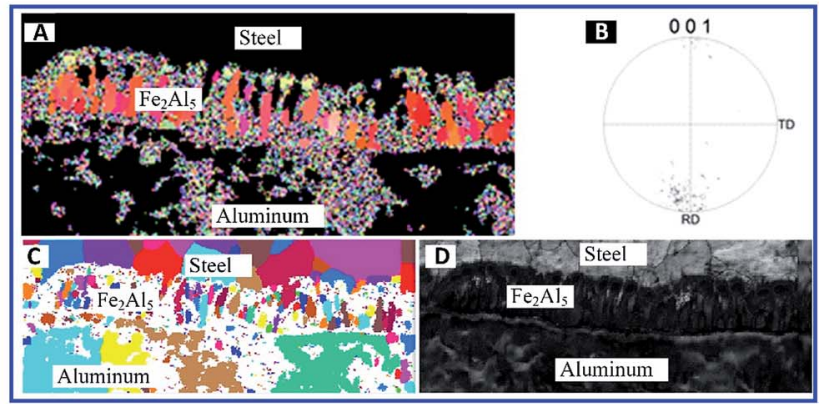

(d)

Fig. 9 EBSD mapping of area I in Fig. 4 for four different weld beads prepared with the welding parameters listed in Table $2\left(I_{\text {total }}=77 \mathrm{~A},(\mathrm{~A})\right.$ image of crystal orientation, (B) pole figure, ( $C$ and D) EBSD color, black-white images of the joint); (a) $I_{\text {bypass }}=0 \mathrm{~A}$ and $I_{\text {main }}=77 \mathrm{~A}$, (b) $I_{\text {bypass }}=22 \mathrm{~A}$ and $I_{\text {main }}=55 \mathrm{~A}$, (c) $I_{\text {bypass }}=32 \mathrm{~A}$ and $I_{\text {main }}=45 \mathrm{~A}$, and (d) $I_{\text {bypass }}=55 \mathrm{~A}$ and $I_{\text {main }}=22 \mathrm{~A}$.

the welding current (heat input) into the base metal did not cause any significant changes in the number of the $\mathrm{Fe}_{2} \mathrm{Al}_{5}$ IMCs. There is only a small portion of $\mathrm{Fe}_{2} \mathrm{Al}_{5}$ IMC with the growth direction along the $c$-axis direction of the $\mathrm{Fe}_{2} \mathrm{Al}_{5} \mathrm{IMC}$, and most
$\mathrm{Fe}_{2} \mathrm{Al}_{5}$ IMCs are oriented disorderly (Fig. 9d). It is known that the mobility of atoms increases with an increase of temperature. Thus, at low temperature, it takes more time for $\mathrm{Al}$ atoms to migrate to the steel to form $\mathrm{Fe}_{2} \mathrm{Al}_{5}$ IMC. Also, the relatively rapid cooling of the molten $\mathrm{Al}$ alloy makes $\mathrm{FeAl}_{3}$ IMC act as a barrier that hinders the migration/diffusion of $\mathrm{Al}$ to the steel side, leading to variations of the morphology and crystal orientation of $\mathrm{Fe}_{2} \mathrm{Al}_{5}$ IMC, as shown in Fig. 9a and $\mathrm{b}$.

In general, the formation and growth of Al-Fe IMCs is dependent on local temperature (heat input), which controls the migration rates of $\mathrm{Al}$ and $\mathrm{Fe}$ atoms. The $\mathrm{Al}-\mathrm{Fe}$ IMCs become barriers to migration/diffusion of $\mathrm{Al}$ and Fe atoms and play an important role in determining the thickness of the IMC layer and crystal orientation of Al-Fe IMCs in the IMC layer.

\subsection{Formation mechanism of the IMC layer}

Based on observations and the above discussion, we propose that formation and growth of $\mathrm{FeAl}_{3}$ and $\mathrm{Fe}_{2} \mathrm{Al}_{5}$ IMCs in $\mathrm{Al}-\mathrm{Fe}$ joints during pulsed DE-GMAW joining can be divided into four stages, as shown in Fig. 10. In the first stage (Fig. 10a), the ER5356 filler wire is melted by the main arc heat, leading to spreading of molten Al to the surface of the steel. This stage mainly involves heat and mass transfer. The second stage is associated with dissolution of $\mathrm{Fe}$ in molten $\mathrm{Al}$ alloy due to transfer of the heat from the melted $\mathrm{Al}$ wire and the main arc heat to the steel as well as migration/diffusion of Al atoms to the steel. Metallurgical reactions occur, resulting in formation of $\mathrm{Fe}_{2} \mathrm{Al}_{5}$ IMC in the interface between the $\mathrm{Al}$ alloy and the steel.

In the second stage, $\mathrm{Fe}_{2} \mathrm{Al}_{5}$ IMC formed in the interface between the $\mathrm{Al}$ alloy and the steel is present in a plate-like shape, as shown in Fig. 10b. The $\mathrm{Fe}_{2} \mathrm{Al}_{5}$ IMC forms an IMC layer sandwiched between the $\mathrm{Al}$ alloy and the steel, resulting in the creation of two new interfaces, including an interface between the $\mathrm{Fe}_{2} \mathrm{Al}_{5}$ IMC layer and the steel and an interface between the $\mathrm{Fe}_{2} \mathrm{Al}_{5}$ IMC layer and the $\mathrm{Al}$ alloy. $\mathrm{Fe}$ and $\mathrm{Al}$ atoms need to migrate through the IMC layer in order to form new AlFe IMCs, which are associated with solid state diffusion instead
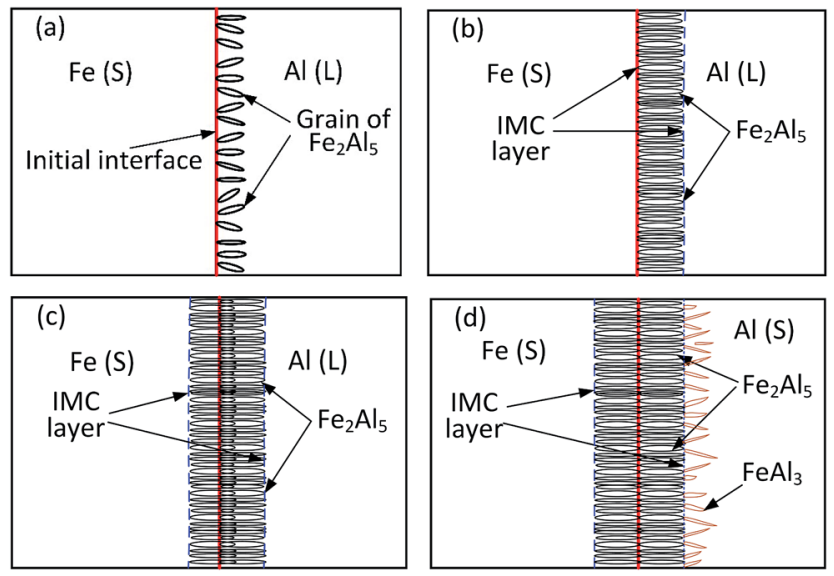

Fig. 10 Schematic diagram of the four stages for formation and growth of the Al-Fe IMC layer; (a) the first stage, (b) the second stage, (c) the third stage, and (d) the fourth stage. 
of solid-liquid reaction. In general, $\mathrm{Al}$ atoms have a higher diffusivity in $\mathrm{Fe}_{2} \mathrm{Al}_{5}$ IMC than iron atoms. Growth of the $\mathrm{Fe}_{2} \mathrm{Al}_{5}$ IMC layer is mainly controlled by the migration/diffusion of $\mathrm{Al}$. This trend leads to the third stage: the formation of a large number of $\mathrm{Fe}_{2} \mathrm{Al}_{5}$ IMCs in the steel and increase in the thickness of the IMC layer, as shown in Fig. 10c.

With formation of the $\mathrm{Fe}_{2} \mathrm{Al}_{5}$ IMC layer, a limited number of $\mathrm{Fe}$ atoms migrate to the $\mathrm{Al}$ alloy. This results in formation of $\mathrm{FeAl}_{3}$ in the $\mathrm{Al}$ alloy around the interface between the $\mathrm{Fe}_{2} \mathrm{Al}_{5}$ IMC layer and the $\mathrm{Al}$ alloy instead of the $\mathrm{Fe}_{2} \mathrm{Al}_{5}$ IMC. The anisotropic characteristics of $\mathrm{FeAl}_{3}$ lead to formation of needlelike structures, as shown in Fig. 10d. Note that the formation of $\mathrm{FeAl}_{3}$ IMC is limited by solid-state diffusion and the decrease of reaction temperature during solidification of the $\mathrm{Al}$ alloy.

\subsection{Numerical simulation of the growth of Al-Fe IMCs}

The MC method was used to simulate formation and growth of the IMC layer observed in the pulsed DE-GMAW joining of the $\mathrm{Al}$ alloy and steel. In the simulation, $400 \times 600$ quadrilateral meshes were used, and the length of the unit lattice was $0.1 \mu \mathrm{m}$. Fixed boundary conditions were used on the edges of the $\mathrm{Al}$ alloy and steel. Sampling frequency and simulation time were 5 $\mathrm{MHz}$ and $4 \mathrm{~s}$, respectively. The parameters used in the analysis were from He et al. work. ${ }^{28}$

Fig. 11 shows temporal variation of the IMC layer sandwiched between $\mathrm{Al}$ and steel substrates at different times for a welding current of $55 \mathrm{~A}$. It is evident that only $\mathrm{Fe}_{2} \mathrm{Al}_{5}$ IMC is present at the early stage, and randomly distributes near the interface between the $\mathrm{Al}$ and steel. From Fig. 11a and b, note that the nucleation and growth of $\mathrm{Fe}_{2} \mathrm{Al}_{5}$ IMCs occur concurrently, resulting in the formation of equiaxed $\mathrm{Fe}_{2} \mathrm{Al}_{5}$ IMCs with a portion of the IMCs in the $\mathrm{Al}$ alloy in a short time period. For the growth (simulation) time being $2.8 \mathrm{~s}, \mathrm{FeAl}_{3} \mathrm{IMC}$ forms due to a decrease of the temperature to the melting point of $\mathrm{Al}$. This result is in accord with the experimental observation and consistent with results reported by Zhang et al. ${ }^{\mathbf{1 8}}$ From Fig. 11c, one can note an increase of the $\mathrm{Fe}_{2} \mathrm{Al}_{5}$ IMC layer due to migration of $\mathrm{Al}$ through the $\mathrm{Fe}_{2} \mathrm{Al}_{5} \mathrm{IMC}$ layer to the steel, which supports the experimental observation.

Fig. 11d presents the final morphology of the Al-Fe IMCs with thickness of the IMC layer being $\sim 11 \mu \mathrm{m}$. The $\mathrm{Fe}_{2} \mathrm{Al}_{5} \mathrm{IMC}$ layer is a plate-like shape, and $\mathrm{FeAl}_{3}$ IMC discretely distributes in the $\mathrm{Al}$ alloy in a needle-like shape. It is important to note that the $\mathrm{Fe}_{2} \mathrm{Al}_{5}$ IMC grows towards the steel and is present in a columnar structure, similar to structures shown in Fig. 5 and there is a preferred direction for growth of the $\mathrm{Fe}_{2} \mathrm{Al}_{5} \mathrm{IMC}$.

Fig. 12 shows numerical results of the morphologies of IMCs at a growth (simulation) time of $4 \mathrm{~s}$ for two different welding currents $\left(I_{\text {total }}=77 \mathrm{~A}\right)$. It is evident that the thickness of the $\mathrm{Fe}_{2} \mathrm{Al}_{5}$ IMC layer decreases with a decrease of the welding current (heat input) into the base metal in accord with the experimental observation (Fig. 5). Also, large welding current (heat input) promotes formation of $\mathrm{FeAl}_{3} \mathrm{IMC}$ in the $\mathrm{Al}$ alloy due to $\mathrm{Fe}$ atoms being able to migrate through the $\mathrm{Fe}_{2} \mathrm{Al}_{5}$ IMC layer to reach the $\mathrm{Al}$ alloy at high temperature. To hinder formation of $\mathrm{FeAl}_{3} \mathrm{IMC}$ and reduce thickness of the $\mathrm{Fe}_{2} \mathrm{Al}_{5}$ IMC layer, one needs to reduce the welding current (heat input) into the base metal.

Fig. 13a shows numerical results of variation of the thickness of the $\mathrm{Fe}_{2} \mathrm{Al}_{5}$ IMC layer with simulation (growth) time. According to Fig. 13a, growth of the $\mathrm{Fe}_{2} \mathrm{Al}_{5}$ IMC layer can be divided into three stages. The first stage is mainly controlled by
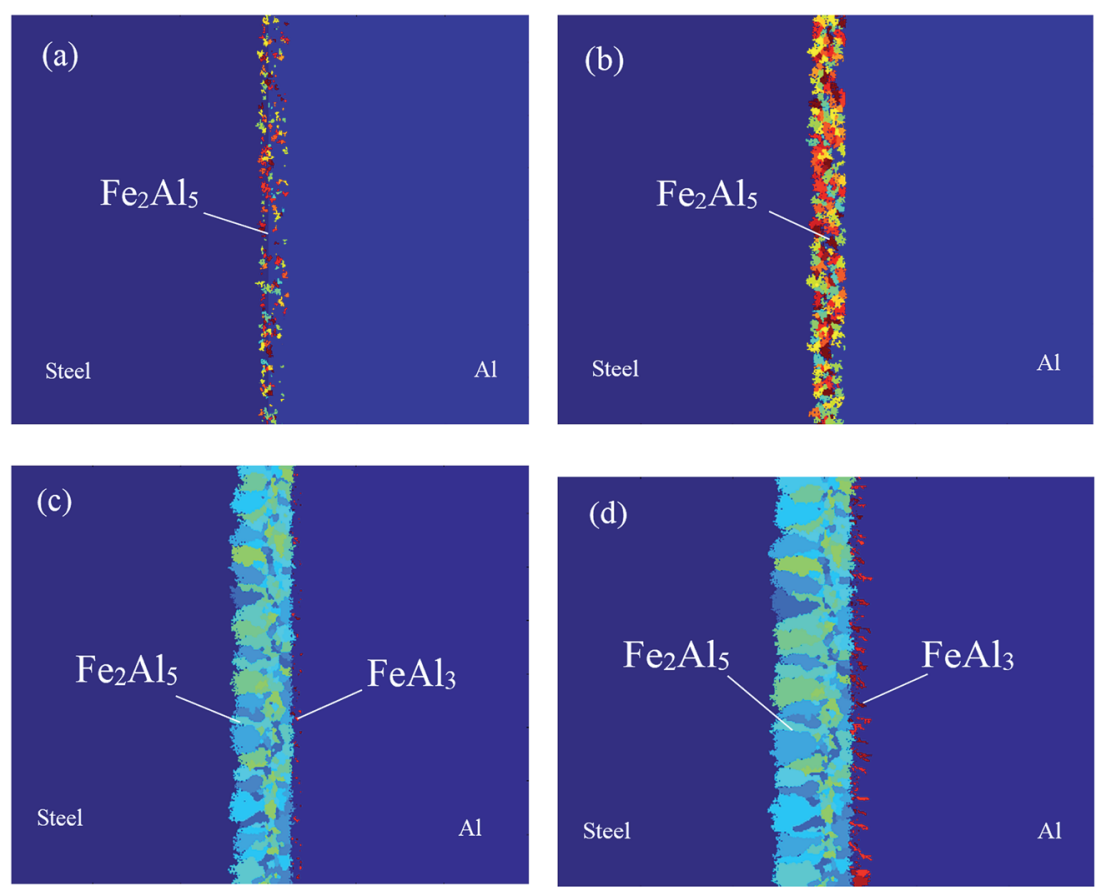

Fig. 11 Temporal variation of the IMC layer sandwiched between Al and steel substrates $\left(I_{\text {main }}=55 \mathrm{~A}, I_{\text {bypass }}=22 \mathrm{~A}\right) ;(\mathrm{a}) t=0.4 \mathrm{~s}$, (b) $t=1.2 \mathrm{~s}$, (c) $t$ $=2.8 \mathrm{~s}$ and $(\mathrm{d}) t=4 \mathrm{~s}$. 

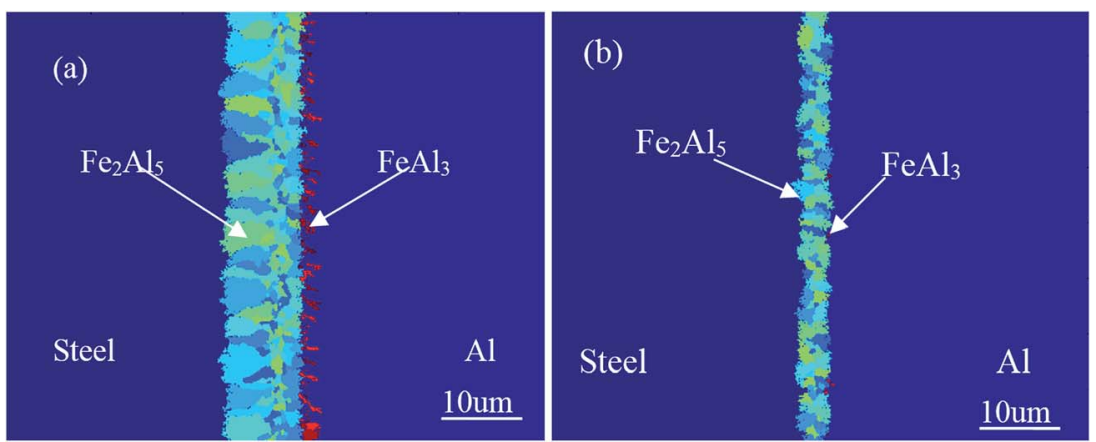

Fig. 12 Numerical results of the morphologies of IMCs at a growth (simulation) time of $4 \mathrm{~s}$ for two different welding currents: $\left(I_{\text {total }}=77 \mathrm{~A}\right)$; (a) $I_{\text {bypass }}=22 \mathrm{~A}, I_{\text {main }}=55 \mathrm{~A}$, and (b) $I_{\text {bypass }}=55 \mathrm{~A}, I_{\text {main }}=22 \mathrm{~A}$.

nucleation of $\mathrm{Fe}_{2} \mathrm{Al}_{5} \mathrm{IMC}$ with a small growth rate. Following the first stage is the second stage with fast growth of the $\mathrm{Fe}_{2} \mathrm{Al}_{5}$ IMC layer. The growth rate of the $\mathrm{Fe}_{2} \mathrm{Al}_{5} \mathrm{IMC}$ layer first increases with an increase of simulation (growth) time, reaches the maximum, and then decreases with an increase of simulation (growth) time. In this stage, growth of the $\mathrm{Fe}_{2} \mathrm{Al}_{5} \mathrm{IMC}$ is associated with dissolution of $\mathrm{Fe}$ in the molten $\mathrm{Al}$ alloy and fast migration/ diffusion of $\mathrm{Fe}$. In the third stage, the local temperature decreases due to solidification, and $\mathrm{Al}$ atoms migrate through the $\mathrm{Fe}_{2} \mathrm{Al}_{5} \mathrm{IMC}$ layer, which reduces the migration rate of $\mathrm{Al}$ and growth rate of the $\mathrm{Fe}_{2} \mathrm{Al}_{5} \mathrm{IMC}$ layer.
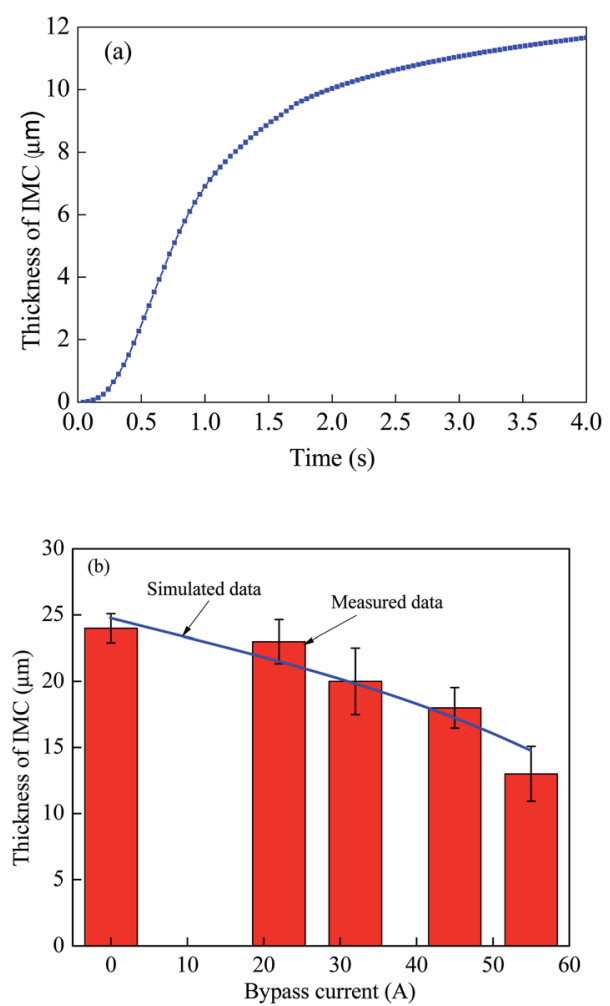

Fig. 13 (a) Variation of the thickness of the $\mathrm{Fe}_{2} \mathrm{Al}_{5}$ IMC layer with a simulation time $\left(I_{\text {main }}=55 \mathrm{~A}, I_{\text {bypass }}=22 \mathrm{~A}\right)$, and $(\mathrm{b})$ comparison between numerical results $\left(t=4 \mathrm{~s}, I_{\text {total }}=77 \mathrm{~A}\right)$ and experimental results $\left(I_{\text {total }}=77 \mathrm{~A}\right)$.
Fig. 13b shows comparison between numerical results for a simulation time of $4 \mathrm{~s}$ and total current of $77 \mathrm{~A}$, and the experimental results for total current of $77 \mathrm{~A}$. It is evident that the numerical results are in good accord with the experimental results, which suggests that assumptions used in the numerical calculation are reasonable. According to the results shown in Fig. 13b, the thickness of the $\mathrm{Fe}_{2} \mathrm{Al}_{5}$ IMC layer decreases with an increase (decrease) of the welding current (heat input) into the bypass (main) circuit. The welding current (heat input) plays an important role in controlling growth of the Al-Fe IMCs. One can use pulsed DE-GMAW joining to control formation and growth of Al-Fe IMCs in order to control the mechanical strength of Alsteel joints.

\section{Conclusions}

Intermetallic compounds play an important role in determining the mechanical strength of dissimilar metallic joints. The pulsed DE-GMAW-brazing process was used in this work to join an Al alloy to a steel plate. Formation and growth of Al-Fe IMCs in the Al-steel joints was studied experimentally and numerically. Important conclusions are summarized below.

(1) Both $\mathrm{Fe}_{2} \mathrm{Al}_{5}$ and $\mathrm{FeAl}_{3}$ IMCs form during the joining. There is a large portion of $\mathrm{Fe}_{2} \mathrm{Al}_{5} \mathrm{IMC}$ which forms an IMC layer. The thickness of the $\mathrm{Fe}_{2} \mathrm{Al}_{5}$ IMC layer increases with an increase of welding current (heat input) into the base metal.

(2) EBSD analysis reveals that a distribution of morphology and size of $\mathrm{Fe}_{2} \mathrm{Al}_{5}$ IMCs exist in an Al-Fe joint. With high welding current (heat input) into the base metal, $\mathrm{Fe}_{2} \mathrm{Al}_{5} \mathrm{IMC}$ is present in a lath-like shape with relatively orderly distribution. There is a preferred direction for growth of the $\mathrm{Fe}_{2} \mathrm{Al}_{5}$ IMC, which is parallel to the normal direction of the (001) plane.

(3) Formation and growth of Al-Fe IMCs can be divided into three stages: (1) nucleation of $\mathrm{Fe}_{2} \mathrm{Al}_{5} \mathrm{IMC}$ in the interface of the $\mathrm{Al}$ alloy and steel, (2) fast growth of the $\mathrm{Fe}_{2} \mathrm{Al}_{5}$ IMC layer associated with dissolution of $\mathrm{Fe}$ in the molten $\mathrm{Al}$ alloy and fast migration/diffusion of $\mathrm{Fe}$, and (3) slow growth of the $\mathrm{Fe}_{2} \mathrm{Al}_{5}$ IMC controlled by diffusion of $\mathrm{Al}$ atoms through the $\mathrm{Fe}_{2} \mathrm{Al}_{5}$ IMC layer. During solidification, $\mathrm{FeAl}_{3} \mathrm{IMC}$ forms in the $\mathrm{Al}$ alloy near the interface between the $\mathrm{Fe}_{2} \mathrm{Al}_{5}$ IMC layer and $\mathrm{Al}$.

(4) The MC method was used to simulate the formation and growth of the Al-Fe IMCs. The numerical results are in good 
accord with the experimental results, and support proposed mechanisms for formation and growth of Al-Fe IMCs in Al-Fe joints. The thickness of the $\mathrm{Fe}_{2} \mathrm{Al}_{5}$ IMC layer increases nonlinearly with an increase of the simulation (growth) time.

\section{Acknowledgements}

This work is funded by the National Natural Science Foundation of China [Grant No: 61365011, 2014; Grant No: 51675256, 2016].

\section{References}

1 G. Pardal, S. Meco, S. Ganguly, S. Williams and P. Prangnell, Int. J. Adv. Manuf. Tech., 2014, 73, 365-373.

2 R. Taban, J. E. Gould and J. C. Lippold, Mater. Des., 2010, 31, 2305-2311.

3 H. Das, S. Basak, G. Das and T. K. Pal, Int. J. Adv. Manuf. Tech., 2013, 64, 1653-1661.

4 D. Travessa, M. Ferrante and G. Ouden, Mater. Sci. Eng., A, 2002, 337, 287-296.

5 M. Acarer and B. Demir, Mater. Lett., 2008, 62, 4158-4160.

6 J. Tsujino, T. Ueoka, T. Kashino and F. Sugahara, Jpn. J. Appl. Phys., 1999, 38, 4254-4255.

7 R. Borrisutthekul, P. Mitsomwang, S. Rattanachan and Y. Mutoh, Energ. Res. J., 2010, 1, 82-88.

8 R. Cao, G. Yu, J. H. Chen and P. C. Wang, J. Mater. Process. Technol., 2013, 213, 1753-1763.

9 Y. C. Su, X. M. Hua and Y. X. Wu, Mater. Sci. Eng., A, 2013, 578, 340-345.

10 M. Sonia, G. Supriyo, W. Stewar and M. Norman, J. Mater. Eng. Perform., 2014, 23, 3361-3370.

11 G. L. Qin, Z. Lei, B. L. Su and X. M. Meng, J. Mater. Process. Technol., 2014, 214, 2684-2692.

12 S. Yang, J. Zhang, J. Lian and Y. Lei, Mater. Des., 2013, 49, 602-612.
13 S. Niu, S. Chen, H. G. Dong and D. S. Zhao, J. Mater. Eng. Perform., 2016, 25, 1839-1847.

14 Y. Shi, J. Li, G. Zhang, J. K. Huang and Y. F. Gu, J. Mater. Eng. Perform., 2016, 25, 1916-1923.

15 A. Das, M. Shome, S. F. Goecke and A. De, Sci. Technol. Weld. Joining, 2016, 21, 303-309.

16 J. L. Song, S. B. Lin, C. L. Yang and G. C. Ma, Mater. Sci. Eng., A, 2009, 509, 31-40.

17 S. Madhavan, M. Kamaraj, L. Vijayaraghavan and K. S. Rao, Trans. Indian Inst. Met., 2016, 1-8.

18 H. T. Zhang, J. C. Feng and P. He, Mater. Sci. Technol., 2008, 24, 1346-1349.

19 L. Shao, Y. Shi, J. K. Huang and S. J. Wu, Mater. Des., 2015, 66, 453-458.

20 M. J. Chen, J. K. Huang, C. C. He, Y. Shi and D. Fan, Acta Metall. Sin., 2016, 52, 113-119.

21 Y. Shi, G. Zhang, Y. Huang, L. H. Lu, J. K. Huang and Y. Shao, Weld. J., 2014, 93, 216-s-224-s.

22 Y. Shi, R. H. Han, J. K. Huang and Y. Shao, J. Manuf. Sci. Eng., 2014, 136, 024502.

23 Y. Shi, R. H. Han, J. K. Huang and D. Fan, Acta Phys. Sin., 2012, 61, 020205.

24 Y. Shi, M. J. Chen, J. K. Huang, Y. F. Gu and D. Fan, Int. J. Mod. Phys. B, 2016, 30, 1650014-1650022.

25 H. Springer, A. Kostka, E. J. Payton, D. Raabe, A. KaysserPyzalla and G. Eggeler, Acta Mater., 2011, 59, 1586-1600.

26 J. J. Zhang, W. Liang and H. T. Li, RSC Adv., 2015, 127, 104954-104959.

27 U. Burkhardt, Y. Grin and M. Ellner, Acta Crystallogr., Sect. B: Struct. Sci., 1994, 50, 313-316.

28 C. C. He, J. K. Huang, Y. Shi and D. Fan, J. Jilin Univ., 2014, 44, 1037-1041. 